ACTA MYCOLOGICA

Vol. 42 (1): 35-58

2007
Dedicated to Professor Alina Skirgietto

on the occasion of her ninety-fifth birthday

\title{
Mycological monitoring in the Hungarian Biodiversity Monitoring System
}

\author{
FERENC PÁL-FÁM ${ }^{1}$, IRÉN SILLER ${ }^{2}$ and LÍVIA FODOR ${ }^{3}$
}

\begin{abstract}
${ }^{1}$ University of Kaposvár, Department of Botany and Plant Production H-7400 Kaposvár, Guba S. 40., pff3@hotmail.com

${ }^{2}$ Szent István University, Faculty of Veterinary Sciences, Department of Botany

H-1077 Budapest, Rottenbiller 50., turcsanyine.siller.iren@aotk.szie.hu

${ }^{3}$ State Secretariat of Nature and Environment Protection, Ministry of Environment and Water

H-1011 Budapest, Fő u. 44-50., kisne@mail.kvvm.hu
\end{abstract}

Pál-Fám F., Siller I., Fodor L.: Mycological monitoring in the Hungarian Biodiversity Monitoring System. Acta Mycol. 42 (1):35-58, 2007.

The results of a mycological monitoring, carried out from 2001 until 2003 in two forest reserves (in the Bükk and the Mecsek Mountains) within the frame of a project of the Hungarian Biodiversity Monitoring System (HBMS) aiming to monitor forest reserves and managed forests, are presented. Standard sampling method had to be developed and methods of data analysis (a so-called protocol) had to be elaborated for monitoring activities.

Key words: macromycetes, fungal monitoring, forest reserves, managed forests, plantations

\section{INTRODUCTION}

Fungi play a very important role in the circulation of matter in ecosystems. Therefore the group of fungi has been also chosen as a component of HBMS. The number of monitoring activities including fungi is relatively low, and the methodology of sampling is not elaborated properly. For this reason thorough investigations and analyses were needed during the development of the monitoring program.

Monitoring means a series of long-term, systematic studies carried out by standardized methods. During elaboration of protocols including the detailed methodological description of sampling and data processing numerous questions have arisen, which demanded new approaches from mycological experts besides application of classical methods.

The work on the methodological basis of fungal monitoring, which, in the meantime, was modified several times according to the collected experiences (Pál-Fám 1999; Rimóczi et al. 2000), was started in 1999 within the framework of HBMS (Rimóczi, Pál-Fám 1999). 
Due to the special life cycle of fungi, choosing among the monitoring methods is a difficult task. Qualitative and quantitative study methods of macrofungi differ from those used in botany or zoology. Mycological monitoring is primarily based on observation of fruit bodies, because vegetative mycelium and mycorrhiza are living in the soil and they are difficult to access and to identify. The study of fruit bodies, however, is not without problems either: their life span is short, their formation is periodical, showing fluctuation and strong dependence on weather, and their ecological functions are very much variable. Monitoring of fungal communities is furthermore hampered by numerous taxonomical problems and the lack of experts.

The question of data processing meant a big challenge, too. Within the frame of HBMS the protocols include methods of establishment of so-called derived data for every group of relevant living beings. However, because of the novelty of fungal monitoring, it was supposed that in the course of evaluation of data, besides the simple variables and indexes, application of diversity measurements and multivariate methods can also help in answering questions arisen and in tracing of changes and trends of fungal communities. In the case of fungi many new proposals were put forward in this field, applicability of which can be decided only after a longer time and on the basis of repeated studies.

Monitoring of fungal communities is realized within the framework of HBMS in the areas of forest reserves. In addition to monitoring of conditions of selected habitats of seminatural state (core areas of forest reserves), tracing of effects of forest management was our intention, too. According to the basic hypothesis of the project, forest management modifies species richness of deciduous forests. In order to settle this question monitoring was carried out in the core areas of the selected forest reserves, in their buffer zones (or managed forests) and also in cultivated forests planted nearby the selected forest community.

Mycological monitoring - after preliminary studies of several years - started in 2001 in two forest reserves in the Bükk and the Mecsek Mountains. On the basis of methods elaborated during the course of preliminary studies the presence of fungi was monitored in permanent sampling plots during periods of 3 years. This length of monitoring period is necessary, because weather dependent appearance of fruit bodies can cause significant differences in the presence of species in consecutive years. That is the reason why summarized results of several years' examination can be considered as one sample. The sizes of sampling plots were determined on the basis of available results and experiences of mycocoenological studies (Pál-Fám 1999, 2001a,b).

\section{GOALS}

The present work aims to demonstrate the first results of biodiversity monitoring of fungal communities in Hungary, and tries to answer some basic questions influencing the further process of monitoring. The goals of monitoring are:

1. identification and assessment of the conservation value of the fungal species in the examined areas;

2. long-term follow-up of characteristics and changes of fungal communities in the involved forests; 
3. comparative monitoring of fungal communities in non-managed core areas of forest reserves, managed stands and forest plantations, in order to examine the effects of management in the latter ones;

4. comparative study of fungal communities of forests situated in different geographical regions and on different base rocks;

5. analysis and comparison of monitored areas in terms of different variables (species number, species diversity, fruit body number, functional diversity) indicating characteristics and changes of fungal communities.

A reliable clarification of several questions is not yet possible. For trend monitoring of fungal communities of forests long-term monitoring is needed, by the means of which a comparison of summarized results of different samples covering several years' periods will become possible.

For commencing mycological monitoring two forest reserves were chosen in which mycological research had been in progress earlier. The work was performed in the "Öserdő" forest reserve in the Bükk Mountains and in the "Köszegi-forrás" forest reserve of the Mecsek Mountains, by the same sampling protocol.

\section{MYCOLOGICAL RESEARCH OF FOREST RESERVES}

In the 1980's several mycologists participated in regular surveys of German forest reserves (Krieglsteiner 1982; Matheis 1985; Haas, Kost 1985; Winterhoff 1989). Veerkamp and Kuyper (1993) completed a mycological survey of sixteen Dutch forest reserves, proving the outstanding role of lignicolous fungal species in these habitats.

The North European mycological school departed from the western and central European ones. Its attention was focused on species inhabiting dead wood (Renvall et al. 1991; Renvall 1995; Høiland, Bendiksen 1996; S tokland 2001). They found, that biodiversity of lignicolous fungi (Aphyllophorales) living in boreal pine forests was influenced by the degree of continuousness of dead wood supply, the distribution pattern of available dead wood, the effects of forest management and the degree of fragmentation of landscape.

Forest management and the age of the forests influence species supply, functional spectrum and diversity of fungal communities. These characteristics can be connected mainly with the quantity and quality of dead wood (trunks, logs, etc.) (Kost, Haas 1989; Siller 2004). This same was formulated by Arnolds as well (1988); according to him aging of forests definitely contributes to the raising number of lignicolous fungi, because the quantity of substrates (branches, logs) available rises.

In Hungary, the results of mycological surveys in the Kékes forest reserve were published by Siller (1986, 1999) and Siller et al. (2002). The fungal communities of the Köszegi-forrás forest reserve of the Mecsek Mountains and of the Öserdő forest reserve in the Bükk Mountains were compared by Siller et al. (2004). The wood decomposing fungi of the Ropolyi forest reserve were surveyed by Tre czker and Szabó (2002). Siller et al. (2004) studied the indicator values of fungal communities in comparison with developmental processes of the forests. Sille r (2004) revealed different biodiversity indicator species in forest reserves. Fod or and PálFám (2000) analyzed functional spectra of fungal communities in different geographical regions (Mecsek, Szigetköz). 
Siller and Maglóczky (2002) summarized the methods of mycological surveys in a methodological series of forest reserve research in Hungary. The authors proposed different research levels and methods (minimum program, long-term study series, aim oriented research) for the mycological study of forest reserves. Among aspects of data evaluation, in addition to the traditional mycocoenological methods they draw attention to the ordination and classification techniques, which are still less used in mycology today. Taking into consideration the bioindicative properties of fungi and the occurrence of Red List species offers further possibilities. Within the framework of comprehensive forest reserve research an opportunity arises to compare results of mycological studies with data of forest structure, soil, microclimate, phytocoenological and forestry investigations.

\section{MONITORING IN MYCOLOGY}

There are only a few examples of long-term, regular mycological monitoring activities based on standardized methodologies. In several cases under the expression of mycological monitoring some repeated surveys or the comparison of the results of two sampling periods are meant.

Under the guidance of Arnolds (1988) and Arnolds and Veerkamp (1999), following some previous comparative analyses, monitoring of 110 mushroom species were accomplished. The Estonian biodiversity monitoring system also aimed at following up habitats of 11 endangered species (Sodermann 1998), but there is no information available about the implementation of the plans.

Mycorrhizal fungi were used as indicators of the impacts of air pollution (Fellner 1989; Fellner, Soukup 1991). Dudka et al. (1994) carried out mycological monitoring in Ukraine in order to predict the future state of forests. Similarly, the results of an eight-year study program performed in Italy, aiming at following up the health condition of forests, was reported by Ambrosi et al. (2002). They measured the biomass of macrofungi in permanent plots.

Nowadays, several researchers (e.g. Lisiewska, Połczynska 1998; Wojewoda et al. 1999; Ławrynowicz et al. 2001; Ławrynowicz 2001) return to the forests studied before with the goal of monitoring. Skirgiełło (1998) studied fungal communities of the forests of Białowieża National Park in permanent plots during 3 years, and then she compared the data with the results of a mycocoenological study, which had been performed 40 years earlier. Several countries plan to include fungi in their biodiversity monitoring programs and claim this work to be under elaboration.

On the basis of the reviewed literature the conclusion can be drawn that the amount of experiences available on standard sampling methods of mycological monitoring and the possibilities of data processing are rather limited. Consequently, the results of the present work may bridge a gap and can be expected to serve as a guidance for researchers of other countries as well. 


\section{MATERIALS AND METHODS}

\section{DESCRIPTION OF SAMPLING AREAS}

The selected plant community was a montane beech forest (Aconito-Fagetum) in the Bükk Mountains and a sessile oak-hornbeam forest (Asperulo taurinae-Carpinetum) in the Mecsek Mountains. Parallel sampling was performed in the core areas of these forest reserves, and in addition, in two managed forests and plantations each in the close vicinity of the reserves.

Sampling areas at the Öserdő Forest Reserve in the Bükk Mountains. Climate of the Bükk Mountains is cool with a montane character. Annual average temperature is $6-7.5^{\circ} \mathrm{C}$, annual precipitation is $800-900 \mathrm{~mm}$. The yearly number of frosty days is above 120 , the average temperature in July is $16^{\circ} \mathrm{C}$. Soil of the monitored forest reserve is brown forest soil with some podsolization in some places. The soil has a $\mathrm{pH}$ of 5.9 on average.

The Öserdő forest reserve is situated in the Bükk Mountains. In an area of 59.3 hectares it is one of the oldest montane beech (Aconito-Fagetum) forests in the country and is protected since 1942. Long time ago it was managed, but forestry management has not occurred for more than 100 years. In the forest, containing also about 180-200 years old tree giants, natural forest developmental processes can be observed. Canopy of the forest is consisted of beech (Fagus sylvatica) and - sporadically and mainly in the marginal parts - maples (Acer pseudoplanatus, A. platanoides) and common ash (Fraxinus excelsior). In the shrub layer - besides the regrowth of the tree species - Rhamnus cathartica, Rosa canina, Sambucus nigra and Ribes uvacrispa can be found. The herb layer is relatively poor, represented only by 61 species (Kárász, Suba 1982). In this layer characteristic plant species of beech forests can be found, as Galium odoratum, Impatiens noli-tangere, Oxalis acetosella, Glechoma hirsuta, Hordelymus europaeus, Sanicula europaea and Viola sylvestris. Montane species of the herb layer are Scopolia carniolica, Senecio nemorensis subsp. fuchsii, Daphne mesereum and Lunaria rediviva.

Core area (B1). A part of the forest reserve being in collapsing phase (with logs and stumps of several collapsed trees in different phases of decay), about the fungal communities of which several years' data are available.

Managed forest (B2). This forest used to be under forestry management (by selective felling), but has been undisturbed for 20-25 years. Wood material of the last felling was left piled up and fallen branches can be found on the ground surface. Its age is approximately 50-60 years and besides the beech (Fagus sylvatica) common ash (Fraxinus excelsior) and maples (Acer pseudoplanatus, A. platanoides) are present in substantial numbers.

Spruce forest (Piceetum cult.) (B3). The plantation was planted into the place of a beech forest. A few beech trees can be found even today in the margins. The Picea abies trees are 40-60 years old. At present it is a completely closed, "nudum" forest. The last thinning - similarly to the managed stand - was carried out 20-25 years ago. Shrub layer can be found only in the marginal parts, consisting mainly of Sambucus nigra. On the ground surface some trunks, logs and branches of collapsed trees can be also found. 
Sampling areas at the Kőszegi-forrás Forest Reserve in the Mecsek Mountains. Climate of the Mecsek Mountains has a submediterranean character. The average annual precipitation is $700 \mathrm{~mm}$. There are two peaks of precipitation: in May-June with $60-80 \mathrm{~mm}$ and in October-November with $60-78 \mathrm{~mm}$. A brown forest soil developed on limestone is typical of the mountains. The $\mathrm{pH}$ of the soil in the monitored area has a value of 4.6-4.8 in the upper $10 \mathrm{~cm}$, whereas with a value of 5.1 in the plantation it is a little bit higher.

All forests monitored were in the potential habitat of the sessile oak-hornbeam community (Asperulo taurinae-Carpinetum) of the Mecsek Mountains. These forests have the largest extension in Mecsek. Because a managed forest of the chosen community can not be found in the vicinity of the reserve, the nearest sessile oak-hornbeam forest was marked out for comparison. Their characteristic species are sessile oak (Quercus petraea), Turkey oak (Q. cerris) and hornbeam (Carpinus betulus). Very few exemplars of silver linden (Tilia tomentosa), wild cherry (Cerasus avium) and maples (Acer campestre, A. platanoides) occur also dispersedly. Characteristic shrubs are Staphylea pinnata and Ruscus aculeatus. In the herb layer Melica uniflora, Carex pilosa, Galium odoratum and Aegopodium podagraria form facies. Typical species of the community are furthermore Helleborus odorus, Doronicum orientale and Lonicera caprifolium.

In the core area (M1) and the managed forest (M2) the canopy consists of sessile oak (Quercus petraea), Turkey oak (Q. cerris) and hornbeam (Carpinus betulus). Beech (Fagus sylvatica), field maple (Acer campestre), wild cherry (Cerasus avium) and the submediterranean floral element silver linden (Tilia tomentosa) can be also found dispersedly. The shrub layer is mainly consisted of the regrowth of the species listed above.

In the plantation (M3) the dominant species is Scots pine (Pinus sylvestris). The shrub layer consists of well developed exemplars of Rubus spp. In the herb layer Carex sylvatica and Melica uniflora form facies.

The core area is a 100-160 years old, non-managed forest, in which - especially in the stream valley and around a spring - several collapsed or standing decaying trees and regrowth of several ages can be found. The core area of 33.2 hectares is not managed in any way. The managed and the planted forests are about 30 years old. In these thinning occurs every year and the dead wood is transported away.

\section{FIELD SAMPLING}

Field sampling was carried out on the basis of the protocol of HBMS. Fungi develop fruit bodies in different periods of the year. In order to manage to register a substantial proportion of species - depending on precipitation - 5-8 samplings per year are necessary mainly in the summer (June-August) and autumn (SeptemberOctober) aspects. Since fruit bodies of a given species in a habitat even in the course of several years can be absent, while its mycelium is present in the substrate, data of one year can not be taken as a complete sample. For this reason, in our monitoring work 3 years' data were considered as one sample.

Borders of the sampling areas were determined by the extensions of the chosen plant communities. Consequently, sampling areas have different sizes $(0.1-316$ hectars, see below). Species lists were prepared at every visit of the investigated areas; 
furthermore qualitative assessments in permanent plots of 500 square meters were also carried out. All fruit bodies of every species were counted. Besides names of species and fruit body numbers the substrates were recorded, too. In this respect plots represented the complete forests. Species names were used following the work of Krieglste in er (1991-93). Table 1 contains sampling dates.

Table 1

Sampling dates at the two sites

\begin{tabular}{|l|l|l|l|l|l|}
\hline \multicolumn{3}{|c|}{ Bükk Mts (Őserdő) } & \multicolumn{3}{c|}{ Mecsek Mts (Kőszegi-forrás) } \\
\hline 10.04 .2001 & 01.05 .2002 & 01.05 .2003 & 02.06 .2001 & 15.06 .2002 & 12.06 .2003 \\
\hline 16.06 .2001 & 31.05 .2002 & 31.05 .2003 & 03.07 .2001 & 28.06 .2002 & 30.06 .2003 \\
\hline 28.07 .2001 & 23.06 .2002 & 28.06 .2003 & 18.09 .2001 & 02.09 .2002 & 28.07 .2003 \\
\hline 29.08 .2001 & 21.07 .2002 & 05.09 .2003 & 01.10 .2001 & 20.09 .2002 & 16.09 .2003 \\
\hline 23.09 .2001 & 20.08 .2002 & 21.10 .2003 & 02.11 .2001 & 20.10 .2002 & 04.10 .2003 \\
\hline 29.10 .2001 & 29.09 .2002 & & & & 19.10 .2003 \\
\hline & 31.10 .2002 & & & & \\
\hline
\end{tabular}

\section{DATA ANALYSIS}

Main methods of data processing were as follows:

1. Monitored areas and sampling plots were compared on the basis of species lists and fruit body numbers of fungal communities.

2. Compositions of the fungal communities in the sampling plots, as suggested by the work of Arnolds et al. (1995), were compared on the basis of life form spectra (functional spectra) concerning data of the separate years and the total of three years alike. Species were classified into the following functional categories: st $=$ soil-inhabiting saprotroph, $\mathrm{pn}=$ necrotrophic parasite, $\mathrm{m}=$ mycorrhizal, $\mathrm{sh}=$ wood-inhabiting saprotroph. The basis of comparison was the number of species belonging to the different groups.

3. Data representing the numbers of fruit bodies of soil- and wood-inhabiting species were analyzed separately because of the different properties of these groups.

a) Rank-abundance curves prepared of the data of the different sampling plots were compared as suggested by Whit taker (1970).

b) Scale-dependent characterization of diversity, based on the data of sampling plots, was carried out by Rényi's generalized entropy-type diversity profile calculation, which can be used for communities of small and big numbers of species alike (Tóthmérész 1993). In every case the results of RTS (Right-Tail-Sum) diversity profiles (Tóth mérész 1997) were examined, too.

4. By application of principal coordinate analysis with Jaccard's distance function (Syntax computer program, Podani 2001) based on cumulative three-year presence-absence data of macrofungi in the investigated forests, the composition of the fungal communities of the different sampling areas were compared.

5. Evaluation of the conservational values of fungi was completed on the basis of the proposed Red List of Hungarian macrofungi (Rimóczi et al. 1999). Names of species are mostly according to Moser (1983). 


\section{RESULTS AND DISCUSSION}

\section{ChARACTERIZATION OF FUNGAL COMMUNITIES}

In the core area in the Bükk Mountains the following species were recorded in relatively large amounts: Bjerkandera adusta, Datronia mollis, Fomes fomentarius, Ganoderma lipsiense, Marasmius alliaceus, Mycena arcangeliana, M. crocata, Panellus stypticus, Pleurotus pulmonarius, Polyporus varius, Schizophyllum commune, Stereum hirsutum, Xylaria hypoxylon, Laxitextum bicolor, a cup fungus (Ascocoryne cylichnicum) and the microfungus Fuligo septica. Among saprotrophic species the following ones reached high abundances: Clitocybe candicans, C. fragrans, C. phyllophila, C. cfr. obsoleta, C. phaeophtalma, Collybia butyracea and Collybia peronata. For mycorrhizal species, amongst which Lactarius subdulcis was prominent, generally a lower abundance was typical. Frequent xylophagous species of the managed forest are Crepidotus applanatus, C. variabilis, Mycena arcangeliana and Psathyrella conopilus. For the plantation typical were Mycena arcangeliana and Stereum sanguinolentum (xylophags) as well as Collybia confluens and C. maculata (saprotrophes).

In the core area from among Aphyllophorales such rare species were found as Antrodiella hoehnelii, A. semisupina, Ceriporia purpurea, Ceriporiopsis gilvescens, Cerrena unicolor, Hericium coralloides, Ganoderma pfeifferi, Skeletocutis nivea, Spongipellis pachyodon and Ischnoderma resinosum. From among cap fungi also several rare species appeared in the monitored areas. Examples are Hydropus subalpinus, Entoloma dichroum, Flammulaster limulatus, Ossicaulis lignatilis and some rare Pluteus spp. The managed forest and the plantation are very poor in rare species.

In the core area of the Köszegi-forrás forest reserve of the Mecsek Mountains Trichaptum biforme had a high abundance. Bjerkandera adusta, Panellus stypticus and Hypholoma fasciculare were also frequent. None of soil-inhabiting saprotrophs produced a significant amount of fruit bodies and among mycorrhizal ones only Lactarius camphoratus is worth mentioning. Frequent species of the managed forest are also xylophags. Such are Stereum hirsutum, Stereum subtomentosum, Hypoxylon fragiforme, Schizophyllum commune, Hypholoma fasciculare and Panellus stypticus. The plantation - besides Hypholoma fasciculare and the soil-inhabiting saprotrophic Mycena rosea - can be characterized mainly by a high abundance of mycorrhizal species, such as Lactarius deliciosus, Paxillus involutus and Amanita pantherina.

All the rare species of the core area are xylophags. To these belong Ganoderma pfeifferi, Hericium coralloides, Hypsizygus ulmarius, Flammulaster muricatus, Ischnoderma resinosum, Laxitextum bicolor, Pluteus leoninus and P. umbrosus. The managed forest is poor in rare species. Agaricus semotus and Coprinus alopecia can be mentioned as examples. Rare species of the plantation, like Amanita pachyvolvata, Cortinarius pseudovariicolor and Lactarius subumbonatus, are all mycorrhizal. 


\section{COMPARISON OF MONITORED AREAS BASED ON SPECIES}

AND FRUIT BODY NUMBERS

Though the sizes of the monitored forests were distinct, difference among species richnesses of core areas, managed forests and plantations seemed to be significant. 224 species were found in the $600000 \mathrm{~m}^{2}$ core area, 88 species in the $3160000 \mathrm{~m}^{2}$ managed forest and 48 species in the $15000 \mathrm{~m}^{2}$ plantation in the Bükk Mountains.

Table 2 demonstrates the numbers of registered species and fruit bodies in the $500 \mathrm{~m}^{2}$ sampling plots in years 2001-2003. In respect of both species and fruit body numbers the core areas of the two monitored locations proved to be the richest ones. The species numbers of the core areas were nearly twice as much as those of the managed and the planted forests. In regard to the fruit body numbers a difference of one order of magnitude can be observed among fungal communities of the core areas, managed forests and plantations.

Table 2

Cumulative numbers of species and fruit bodies of the macrofungal communities in the 500 $\mathrm{m}^{2}$ sampling plots in years 2001-2003

\begin{tabular}{|c|c|c|}
\hline Sampling plot & Number of species & Number of fruit bodies \\
\hline B1 & 149 & 33103 \\
\hline B2 & 78 & 3350 \\
\hline B3 & 66 & 3163 \\
\hline M1 & 67 & 8185 \\
\hline M2 & 38 & 1898 \\
\hline M3 & 40 & 552 \\
\hline
\end{tabular}

Explanations: B1: core area, Bükk Mts B2: managed forest, Bükk Mts B3: plantation, Bükk Mts M1: core area, Mecsek Mts M2: managed forest, Mecsek Mts M3: plantation, Mecsek Mts.

When the two locations are compared, it can be established that the sampling areas in the Bükk Mountains are richer regarding species and fruit body numbers. This fact can be explained first of all with a drier climate in the Mecsek Mountains. In addition, the shallower, rocky soil of the core area in the last one, the different ages of the two forests (Öserdő in the Bükk Mountains is about 150-200 years old, whereas the reserve in the Mecsek Mountains is about 120-160 years old), and the substantial difference in the duration without any disturbance might have contributed to differences.

\section{FUNCTIONAL CHARACTERIZATION OF FUNGAL COMMUNITIES}

Composition, structure and age of vegetation in addition to environmental conditions have a strong effect on the composition, species supply and quantitative relations of the fungal community developing in a site. Thus functional spectra of the fungal communities indicate characteristics of the vegetation and its other environmental conditions. 
Table 3

Total numbers of species of different functional groups of the macrofungal communities identified within 3 years in the sampling plots

\begin{tabular}{|c|c|c|c|c|}
\hline Sampling plot & sh & pn & m & st \\
\hline B1 & 92 & 13 & 7 & 37 \\
\hline B2 & 41 & 4 & 2 & 31 \\
\hline B3 & 26 & 2 & 9 & 29 \\
\hline M1 & 42 & 12 & 2 & 11 \\
\hline M2 & 21 & 2 & 11 & 4 \\
\hline M3 & 6 & 0 & 26 & 8 \\
\hline
\end{tabular}

Explanations: B1: core area, Bükk Mts B2: managed forest, Bükk Mts B3: plantation, Bükk Mts M1: core area, Mecsek Mts M2: managed forest, Mecsek Mts M3: plantation, Mecsek Mts, sh: lignicolous species, pn: necrotrophic parasites, m: mycorrhizal species, st: terricolous saprotrophic species.

Figure 1 demonstrates the functional spectra of fungal communities of the sampling plots calculated by summarization of the data of three years (see Table 3). It is conspicuous that proportions of lignicolous (sh) and necrotrophic parasite (pn) species are decreasing in the core area - managed forest - plantation order of succession. The reason of this is that the precondition of the survival of these species is the presence of dead wood material of different quality and big quantity. The presence of dead wood can not only help the survival of many species, but, in the case of seminatural forest management, offers possibilities for a new dispersal. Proportional decrease of lignicolous and necrotrophic parasite species in the mentioned order of succession is more significant in the Mecsek Mountains, than in the Bükk Mountains. Probably, this decrease indicates the effects of management, namely species belonging to these groups get clearly rarer as human influence grows, i.e. the proportion of dead wood decreases.

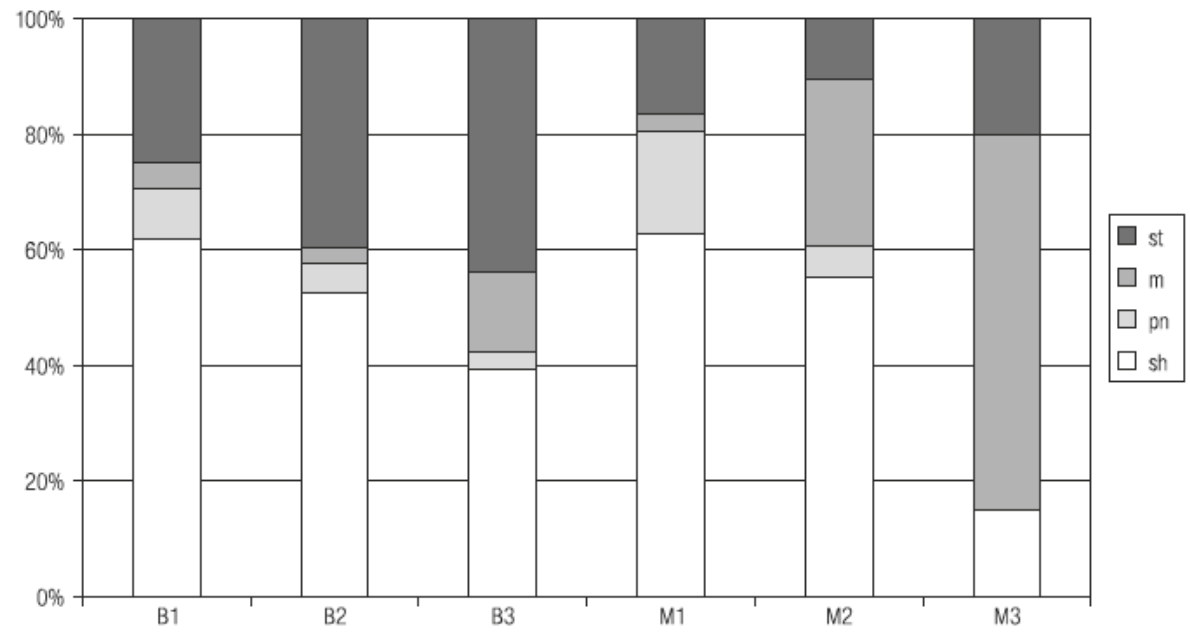

Fig. 1. Life form distribution (in \%) of the macrofungi of the sampling plots in the Bükk and the Mecsek Mountains based on the summarized data of the years 2001-2003.

Explanations: $\mathrm{sh}=$ lignicolous species, $\mathrm{pn}=$ necrotrophic parasites, $\mathrm{m}=$ mycorrhizal species, st = terricolous saprotrophs; $\mathrm{B}=$ Bükk Mts, $\mathrm{M}=$ Mecsek Mts;

$1=$ core area, $2=$ managed forest, $3=$ plantation. 
B1
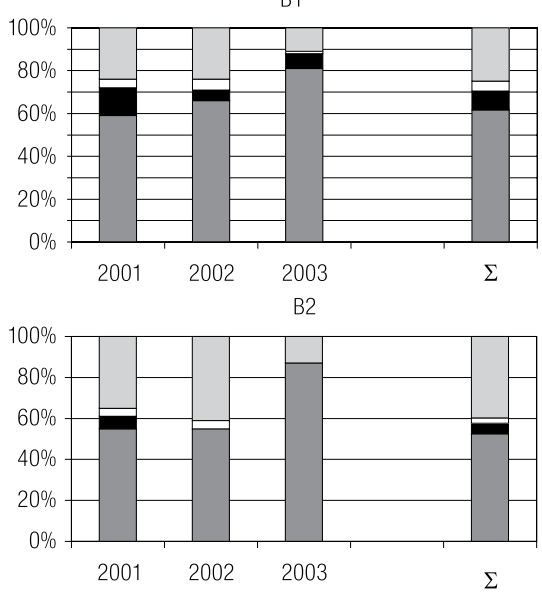

B3

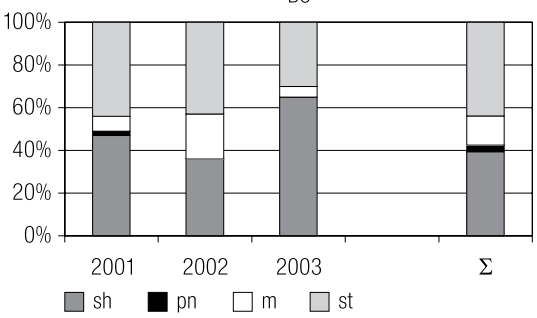

M1

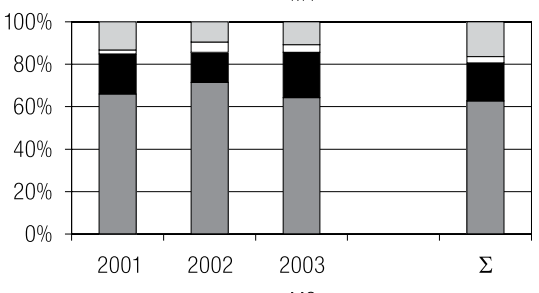

M2
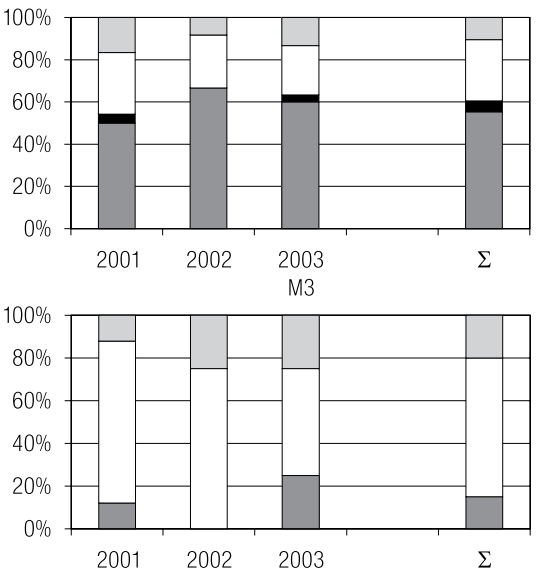

Fig. 2. Life form distribution (in \%) of the sampling plots and in the aggregated samples $(\Sigma)$ in the Bükk and the Mecsek Mountains based on the separate and the summarized data of the years 2001-2003.

Explanations: $\mathrm{sh}=$ lignicolous species, $\mathrm{pn}=$ necrotrophic parasites, $\mathrm{m}=$ mycorrhizal species, $\mathrm{st}=$ terricolous saprotrophs; $\mathrm{B}=$ Bükk Mts, $\mathrm{M}=$ Mecsek Mts; 1 = core area, 2 = managed forest, $3=$ plantation.

A relatively high ratio of mycorrhizal species in the plantation in the Bükk Mountains does not coincide with a higher number of mycorrhizal species as well; it is much more a consequence of driving back of saprotrophs (sh) and necrotrophic parasites (pn) by management. Nevertheless, concerning the Mecsek Mountains, in the background of the higher ratio of mycorrhizal species in the managed forest and the plantation, there is a significant increase in species numbers, too. In most cases the proportion of soil-inhabiting saprotrophs (st) is higher in the managed forests and the plantations than in the core areas. This is, however, resulted in by the low number of lignicolous species, whereas the species number of saprotrophs is decreased. This suggests that in comparison with the managed forests and the plantations, the reserves provide more favorable conditions even for the soil-inhabiting saprotrophic communities.

Whereas the functional spectra of the two forest reserves seem to be fairly similar, this same is not true for the two managed forests, and is even less true for the two plantations. This, in addition to the different tree species compositions and mycorrhizal partners present, might probably be the consequence of the different soils, ages and managements of the forests. 
Figure 2 shows the functional spectra of the fungal communities of the plots in the different years. It seems that in both locations the spectra of the different years show higher fluctuation in the managed forests and the plantations than in the forest reserves. This suggests, that the core area provides more balanced conditions for the fungal communities, than the other two sites. In the case of the Bükk Mountains the spectra of the years 2001 and 2002 show high similarity, whereas in 2003 conspicuous is the increased dominancy of lignicoles (sh). Though according to our knowledge the functional spectrum is a stable characteristic of the fungal community of a given habitat, this result indicates that in a dry period (like the year 2003), which is not favorable for developing fruit bodies, the spectrum can be changed towards a more definite dominance of lignicolous species. This can be explained by the fact, that wood retains humidity better than soil. In the case of Mecsek, which has drier climate than the Bükk Montains, drought in the year of 2003 did not result in similar changes.

\section{ANALYSIS BASED ON FRUIT BODY NUMBER}

Studies of fungal communities by rank-abundance curves help to analyze their structure. The method is mostly used for the analysis of the structure of plant communities. Communities being in an early stage of development are mainly characterized by a geometric series, whereas communities, which are rich in species, have more or less log-normal or "broken stick" distribution (Ma gu rra n 1988). Whereas the latter type shows a balanced distribution of abundances, the geometrical series indicates small number of species and an extremely unequal distribution of abundances within the community. According to our knowledge, this method has not been applied for fungal communities yet.

Diversity profiles give further informations about the structure of the studied community, which can not be acquired from rank-abundance curves. At 0 scale parameter the values shown by the curves depend on the number of species, whereas at bigger values of scale parameters the shape of the curve is influenced in a growing extent by the presence of dominant species.

Because of the different behaviour of species inhabiting trees (sh, pn) and soils ( $\mathrm{m}, \mathrm{st})$, these groups were considered during our analyses as different communities.

\section{CHARACTERIZATION OF LIGNICOLOUS, WOOD-INHABITING FUNGAL COMMUNITIES}

Rank-abundance curves of the lignicolous fungal communities (which include species of the groups sh and pn) of the different sampling sites show that the core areas have the highest species numbers and the most balanced distribution of species abundances (Figs 3 and 4). The fewer species of the fungal communities of the managed forests, however, have a rather unequal distribution. Consequently, the ability of the old, unmanaged forests, to preserve a great number of species, is better, than that of the managed forests, presumably because the first ones are able to provide more structured habitats. On the contrary, there is only a limited amount of dead wood in the managed forests, because actually all the timber cut down is transported away for utilization, and thus these forests provide less substrates - presumably also with lower variability and quality - for fungi. The smallest number and the most uneven distribution of lignicolous species can be detected in the plantations. These 


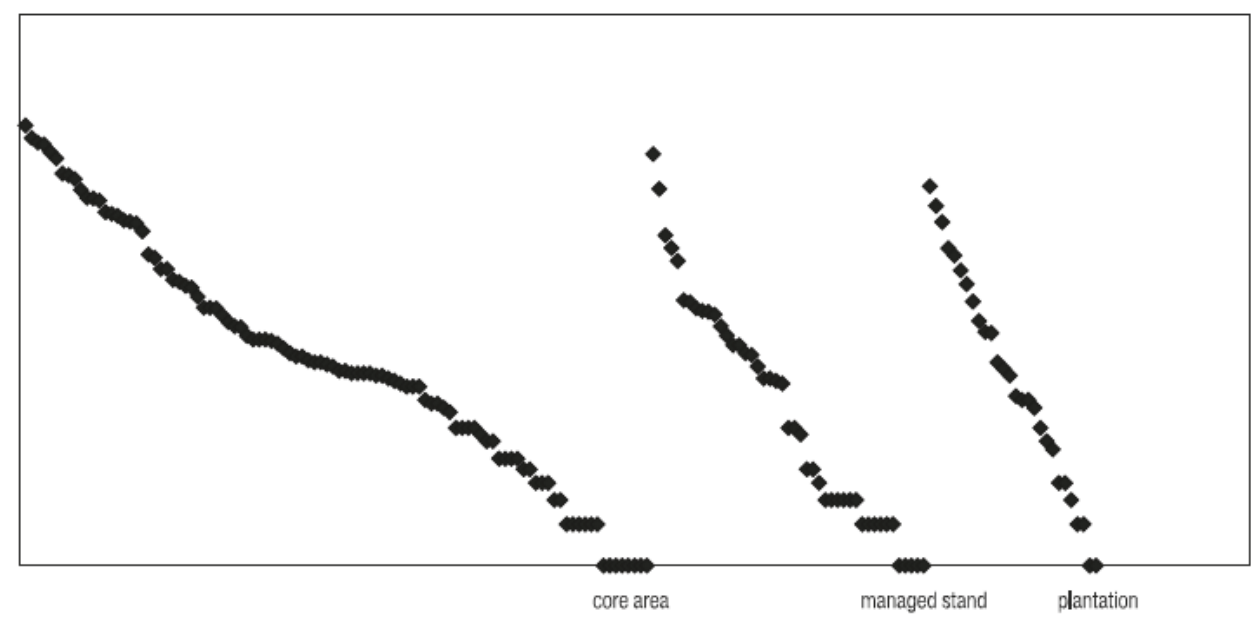

Fig. 3. Rank-abundance curves of the lignicolous macrofungal communities of the sampling areas (core area, managed forest, plantation) of the Bükk Mts.

Explanation: $\mathrm{x}$-axis shows species numbers.

habitats seem to be rather unfavorable for the lignicolous species. Probably here the species do not form a real community; their presence is more or less accidental.

Diversity profiles are suitable for the analysis of factors influencing diversity. Whereas at 0 scale parameters they show the logarithm of the species numbers (which, in practice, is high if a great number of species are present with low abundances), at high scale parameters the presence of some species with high abundances has the largest impact upon the curve, by pressing it down to lower positions. Consequently, at higher scale parameters, the evenness of the abundances has a definitive role in determining diversity profiles. Taking then into consideration species num-

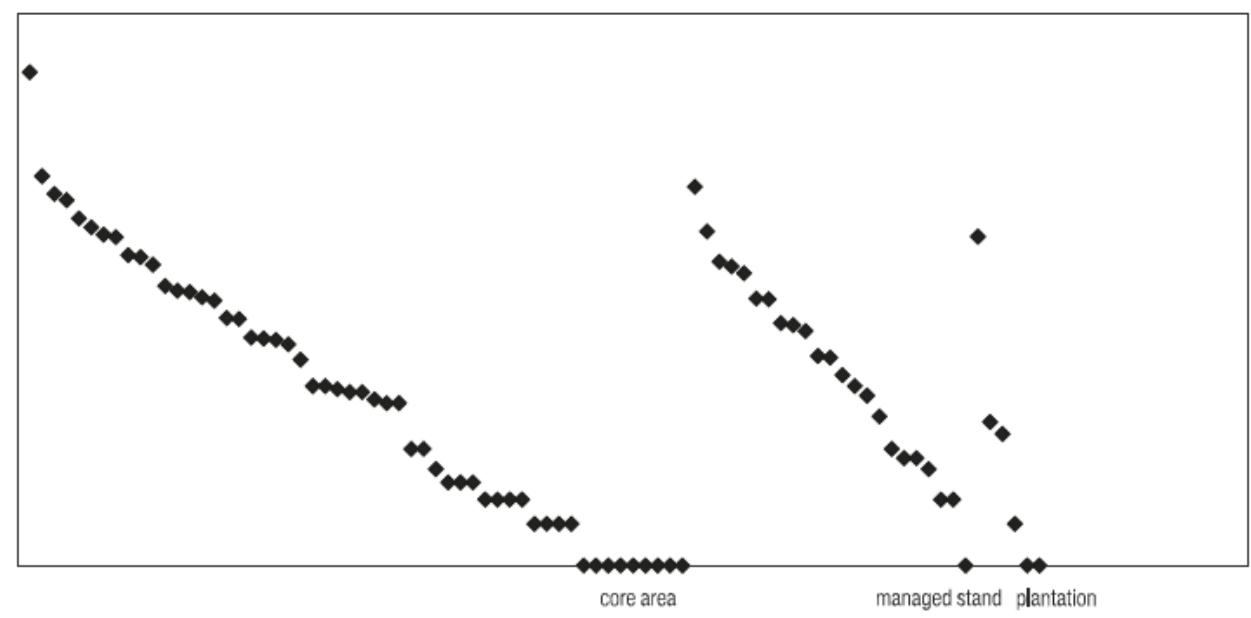

Fig. 4. Rank-abundance curves of the lignicolous macrofungal communities of the sampling areas (core area, managed forest, plantation) of the Mecsek Mts.

Explanation: $\mathrm{x}$-axis shows species numbers. 


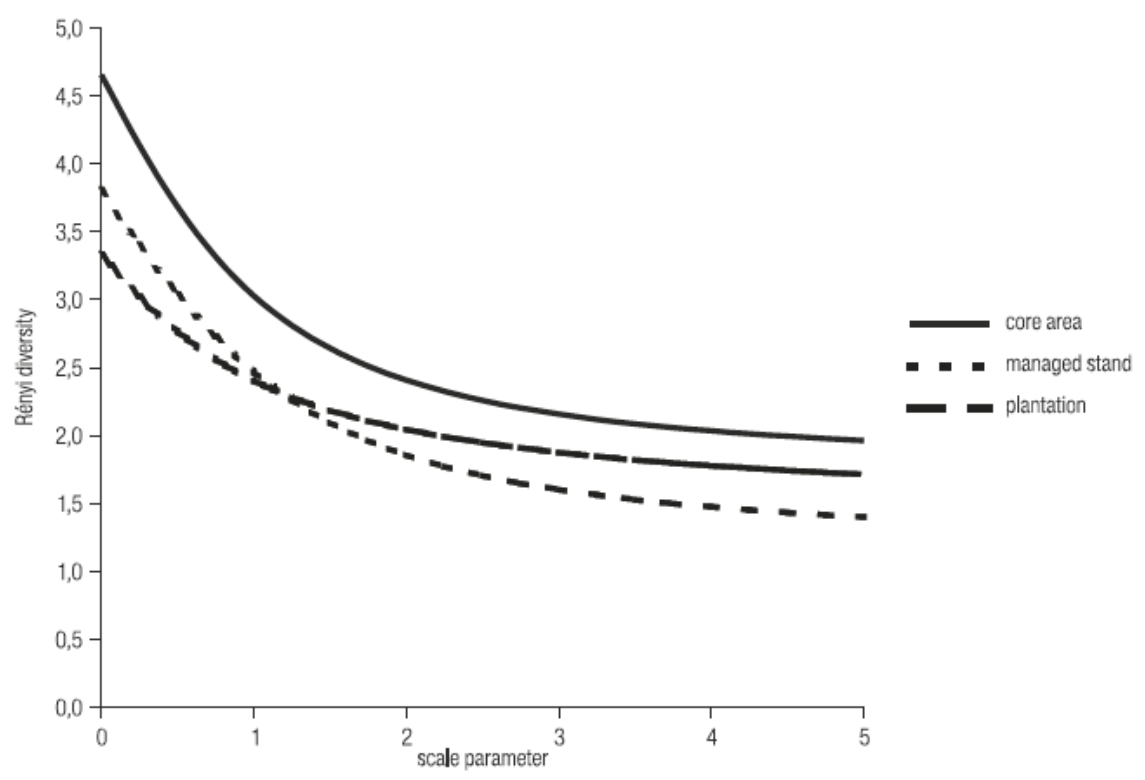

Fig. 5. Diversity ordering of the lignicolous macrofungal communities of the sampling areas (core area, managed forest, plantation) of the Bükk Mts.

bers, it can be established, to what extent are high diversities shown by the curves determined by the presence of a high number of low abundance species or of a relatively low number of medium abundance species.

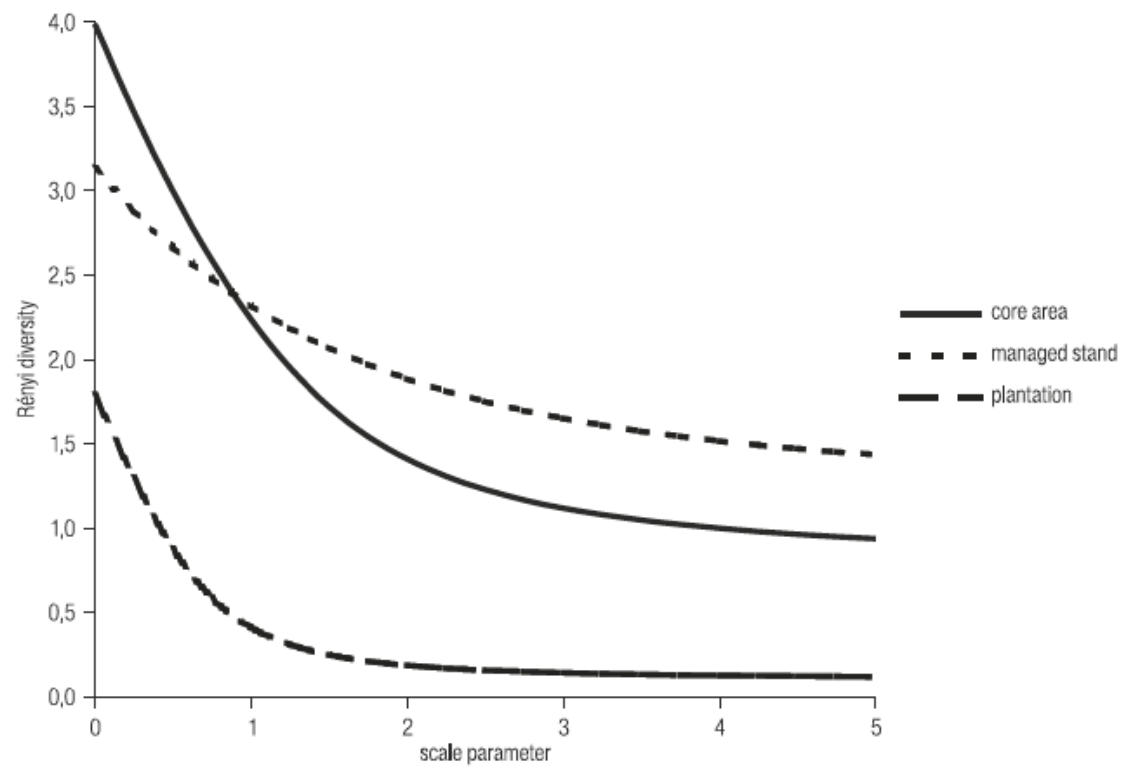

Fig. 6. Diversity ordering of the lignicolous macrofungal communities of the sampling areas (core area, managed forest, plantation) of the Mecsek Mts. 
Diversity profiles (Figs 5 and 6 ) of the investigated fungal communities show at 0 scale parameters that in respect of species numbers the core areas are the most diverse in both locations. This also demonstrates the importance of these areas in the survival of many species of low abundances. In respect of evenness (see at high scale parameters), however, the core area in the Bükk Mountains and the managed forest of the Mecsek Mountains are the most diverse. Taking into consideration the relatively low number of species present in the managed forest of the Mecsek Mountains, it can be concluded, that forest management does not have such a large impact upon the species of medium abundances in this forest, which would endanger their survival; moreover, it is possible that management favors their spread. Plantations are the least diverse in every aspects, showing the negative impact of plantation management onto most species.

\section{CHARACTERIZATION OF SOIL-INHABITING FUNGAL COMMUNITIES}

In the case of soil-inhabiting fungi the climatic conditions of the area, the vegetation, the soil type, the humus content and other features of the soil play a substantial role in the composition of the community. On the basis of rank-abundance curves (Fig. 7) it can be established that in the Bükk Mountains the soil-inhabiting fungal community of the core area has the most complicated structure: one very high abundance species is accompanied by several low abundance ones. Between the soilinhabiting fungal communities of the managed stand and the plantation significant difference can not be established.

In the Mecsek Mountains fungal communities of the plantation show the most balanced distribution of abundances, with the highest number of species (Fig. 8).

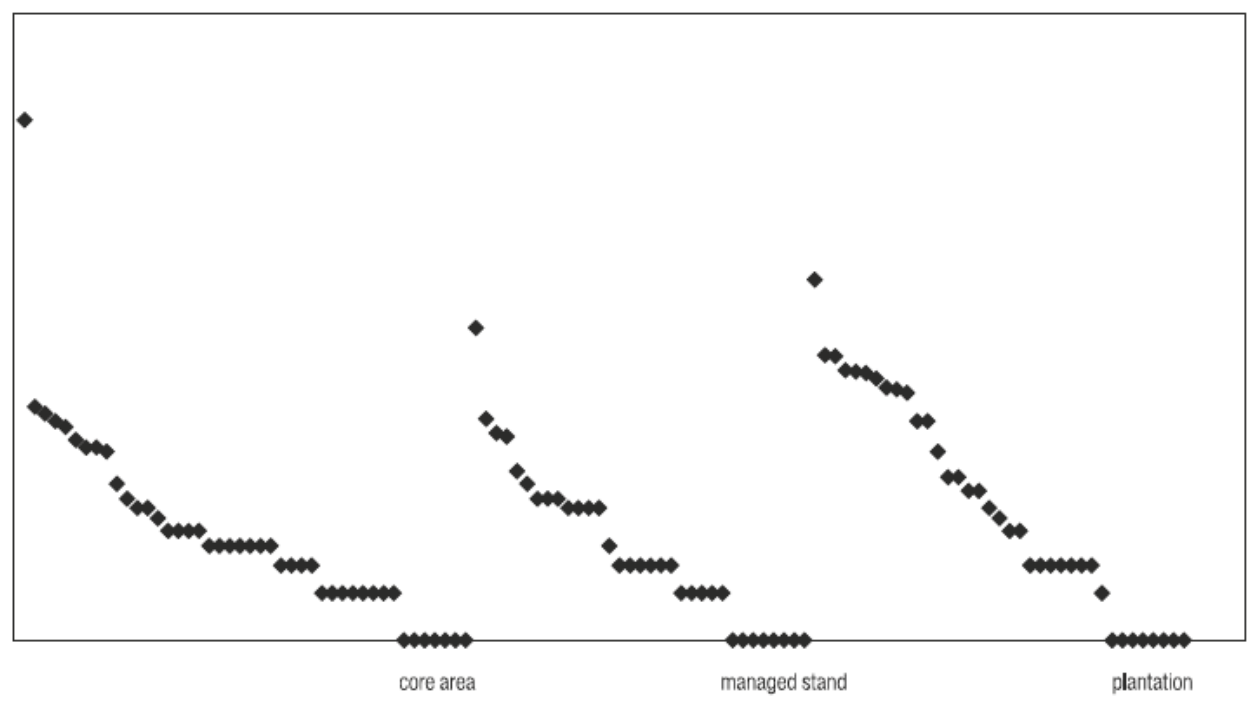

Fig. 7. Rank-abundance curves of the soil-inhabiting macrofungal communities of the sampling areas (core area, managed forest, plantation) of the Bükk Mts. Explanation: $\mathrm{x}$-axis shows species numbers. 


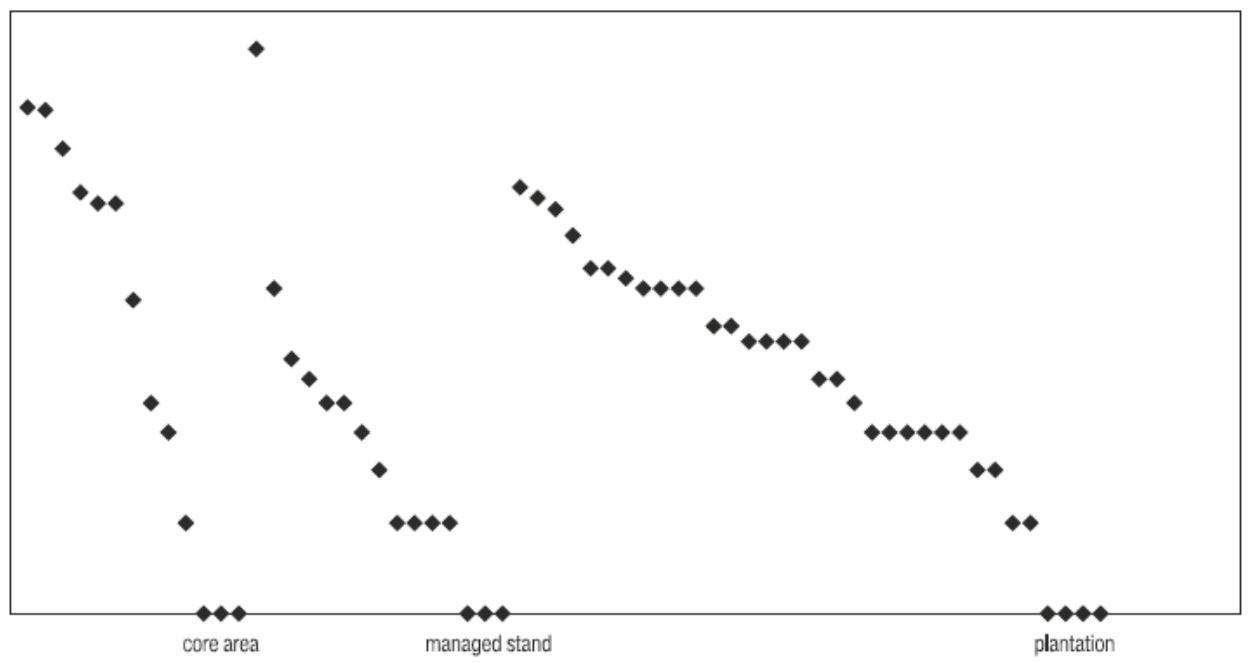

Fig. 8. Rank-abundance curves of the soil-inhabiting macrofungal communities of the sampling areas (core area, managed forest, plantation) of the Mecsek Mts.

Explanation: $\mathrm{x}$-axis shows species numbers.

Fungal community of the core area is very simply structured and has a small number of species due to its shallow, rocky soil.

Diversity profiles of the fungal communities of the two locations (Figs 9 and 10) show significant differences. Whereas in the Bükk Mountains the core area has the highest species number (see at 0 scale parameter), at higher scale parameters

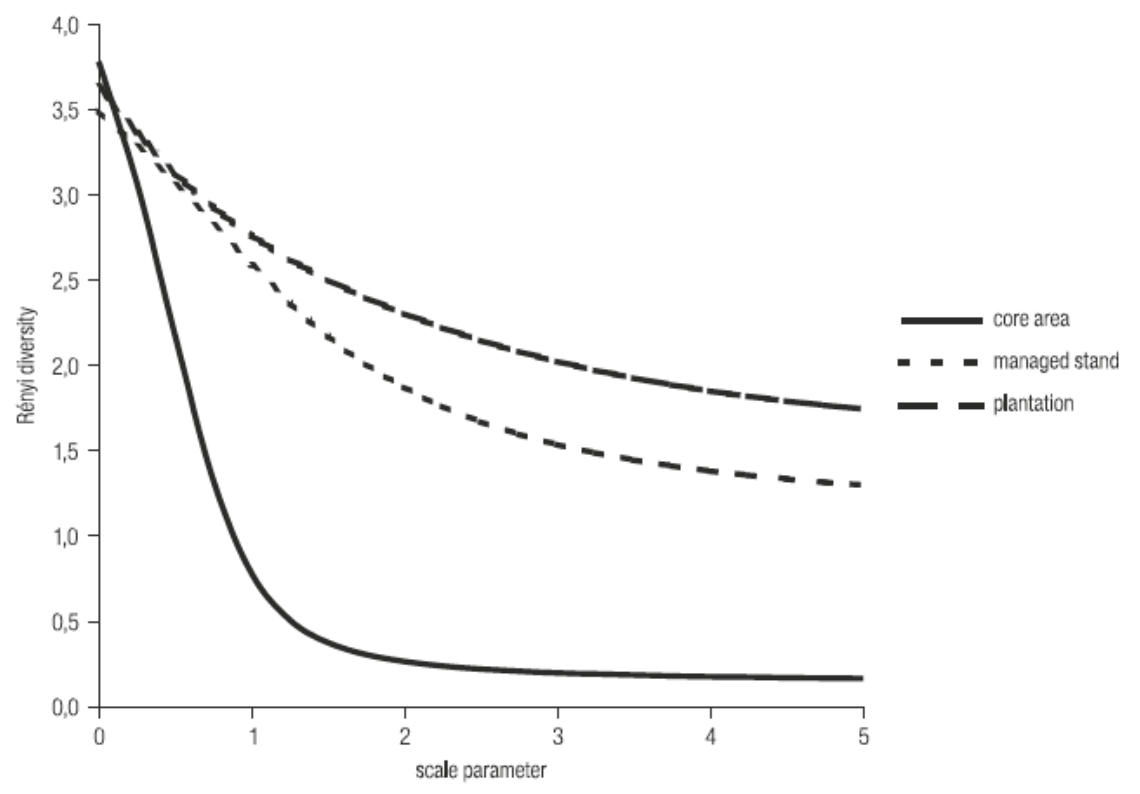

Fig. 9. Diversity ordering of the soil-inhabiting macrofungal communities of the sampling areas (core area, managed forest, plantation) of the Bükk Mts. 


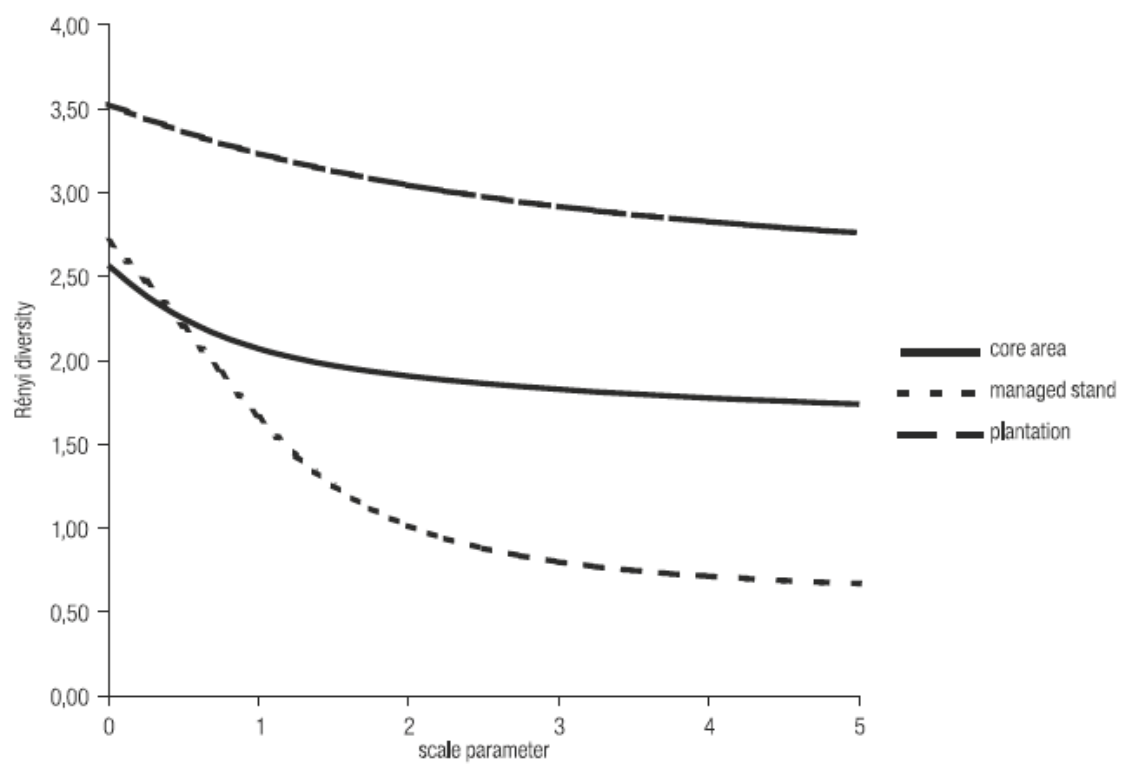

Fig. 10. Diversity ordering of the soil-inhabiting macrofungal communities of the sampling areas (core area, managed forest, plantation) of the Mecsek Mts.

the extremely high abundance of one species (Marasmius alliaceus) brings down the diversity values below those of the other two sampling sites. In the case of the investigated sites of the Mecsek Mountains at all scale parameters the planted forest is the most diverse, and, in regard to species numbers (see at 0 scale paramater), the managed forest is the second in the rank of order. At higher scale parameters - due to the absence of species of very high abundance - the core area is more diverse, than the managed forest.

On the basis of the results presented it can be established, that, while the presence of decaying wood caused significant similarities between the structures of the lignicolous communities of the Bükk and the Mecsek Mountains' forest reserves, the same - because in the significant difference in the edaphic conditions - is not true for the soil-inhabiting communities. Probably, the favourable edaphic conditions (deeper, more humid soil) increase, whereas the unfavorable ones decrease the diversity of soil-inhabiting fungal communities. In the mirror of this it is especially interesting, that in forests of so different edaphic conditions how similar is the diversity structure (without necessary similarities in the constituting components) of the fungal communities developing on decaying wood.

\section{MULTIVARIANTE ANALYSES}

Results of principal coordinate analysis in the case of wood-inhabiting fungal communities (Fig. 11) separated well the two sampling locations along the first axis. Along the second axis, however, different management separated only the plantations from the other sampling sites. Remarkable is the difference between the two locations in regard to distances among the different types of management: fungal 


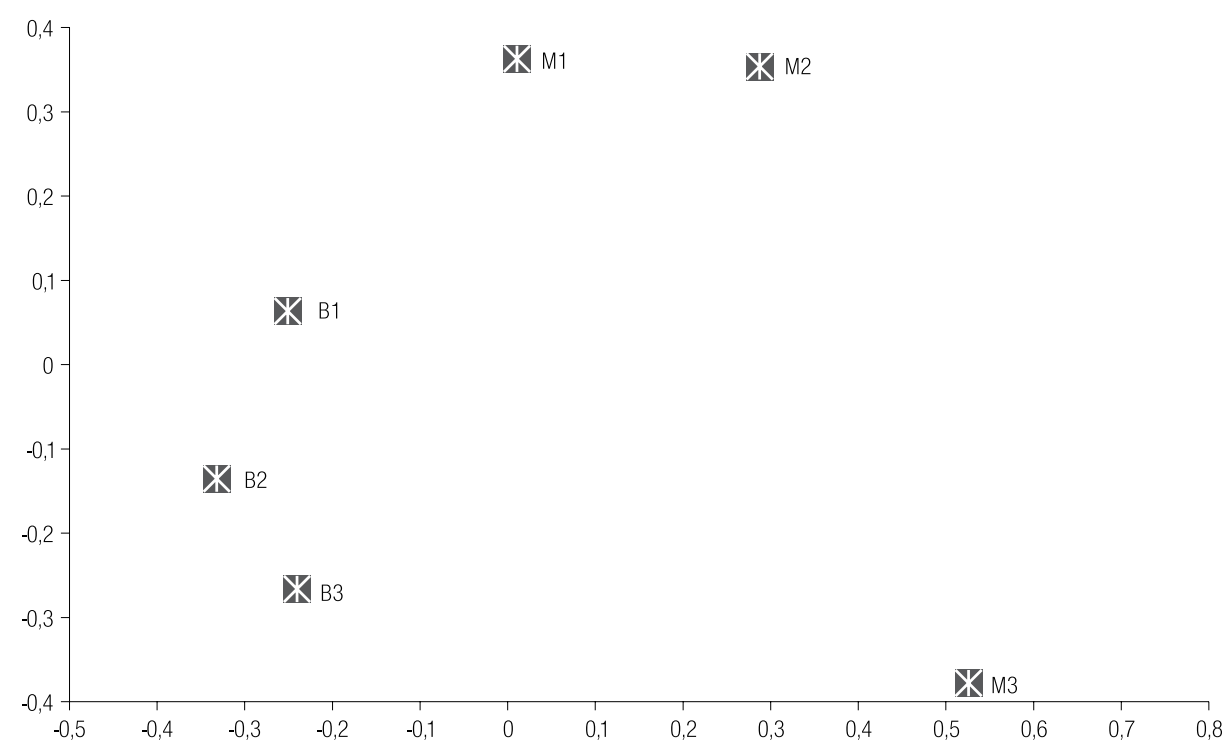

Fig. 11. Ordination (PcoA analysis based on the coefficient of Jaccard) of the lignicolous fungal communities of the sampling sites of the Bükk and Mecsek Mts.

Explanations: $1=$ core area (B1), $2=$ managed forest (B2), $3=$ plantation (B3) in the Bükk Mts; $4=$ core area (M1), $5=$ managed forest (M2), $6=$ plantation (M3) in the Mecsek Mts; variance: axis 1: 29\%, axis $2: 24 \%$.

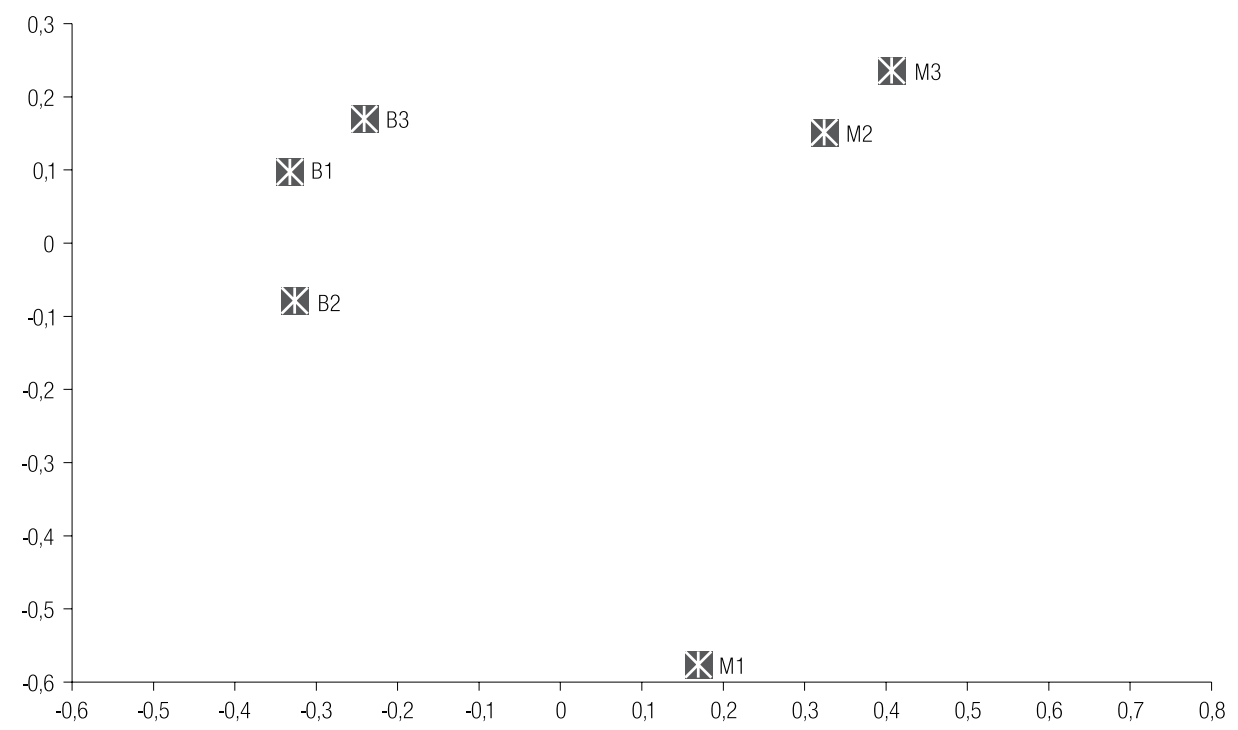

Fig. 12. Ordination (PcoA analysis based on the coefficient of Jaccard) of the soil-inhabiting fungal communities of the sampling sites of the Bükk and Mecsek Mts.

Explanations: $1=$ core area (B1), $2=$ managed forest (B2), $3=$ plantation (B3) in the Bükk Mts; $4=$ core area (M1), $5=$ managed forest (M2), $6=$ plantation (M3) in the Mecsek Mts; variance: axis 1: 27\%, axis $2: 21 \%$. 
communities in the Bükk Mountains are more similar to each other, than those of the Mecsek Mountains. The significant separation of the plantation of the Mecsek Mountains from the other sampling sites of the same mountains is probably due to its lower species number and the bigger geographical distance from the other sampling sites.

Principal coordinate analysis of the data representing soil-inhabiting fungal communities gave a similar result (Fig. 12). Most significant is the difference between the two locations and the samples from the Bükk Mountains are less scattered than those from the Mecsek Mountains. The core area of the forest reserve in the Mecsek Mountains is remarkably separated from all other samples, suggesting that the species compositions of the investigated managed forest and plantation of the Mecsek Mountains are closer to each other, than to the similar feature of the core area. This supports the idea about the indicator values of fungi, that is, they indicate the less favourable characteristics of the shallow and rocky soil of the core area, as compared to the soils of the managed forest and the plantation. Similarly to previous experiences (Fod or 2003; Siller et al. 2004), this monitoring confirms that the composition of fungal communities is strongly influenced by the geographical situation, management practices and other environmental conditions of habitats.

Our results suggest, that the significantly different species compositions of the different forest types existing in the proximity of each other make up together extraordinarily big species richness. This statement is supported by the results of our diversity studies, too.

\section{EVALUATION OF THE MONITORED AREAS FROM THE POINT OF VIEW OF CONSERVATION}

Substantial part of species found in the monitored areas is also included in the recommended Red List of macrofungi in Hungary (Rimóczi et al. 1999). In the Red List species are assigned to different categories on the basis of their endangerment following the recommendations of IUCN (1994). Category 1 includes the most endangered species, whereas category 4 includes those, which are also endangered, but occur more frequently.

Among species assigned to categories 1 and 2 (most endangered) 12 were found in our samples from the Bükk and the Mecsek Mountains. On the basis of the number of endangered species, the prominent conservation value of the two core areas is clear (Tab. 4). Species falling into IUCN category 2 can be practically found only here. These species are missing from the managed forests and the plantations monitored simultaneously, what refers to the fact, that rare species with special ecological demands find their life conditions only in undisturbed, unmanaged, natural or seminatural forests. Lignicolous fungi demand dead wood material of different sizes and in different phases of decay, as substrate. Species listed in category 3 of IUCN occurred also in the plantations in big quantities. This can be explained by the fact, that many species of these plantations are connected to conifers, habitats of which are not indigenous in the monitored areas of Hungary. 
Table 4

Numbers and IUCN categories of endangerment of species that are listed in the draft Hungarian Red List of macrofungi, found in the sampling sites

\begin{tabular}{|c|c|c|c|}
\hline Sampling site & IUCN 1-2 & IUCN 3 & IUCN 4 \\
\hline B1 & 10 & 38 & 15 \\
\hline B2 & 1 & 21 & 3 \\
\hline B3 & 1 & 29 & 1 \\
\hline M1 & 6 & 17 & 15 \\
\hline M2 & 0 & 6 & 1 \\
\hline M3 & 0 & 24 & 2 \\
\hline
\end{tabular}

Explanations: B1: core area, Bükk Mts. B2: managed forest, Bükk Mts. B3: plantation, Bükk Mts. M1: core area, Mecsek Mts. M2: managed forest, Mecsek Mts. M3: plantation, Mecsek Mts.

\section{CONCLUSIONS}

On the basis of the results of our monitoring activities in selected core areas of forest reserves, managed forests and plantations in the Bükk and the Mecsek Mountains in Hungary it can be established that the core areas are extremely rich in both species and fruit body numbers, thus being qualified as the best habitats in regard to wood-inhabiting fungi. On the basis of the presence of endangered species the core areas seem to be also important habitats for the species of special ecological demands. Among fungal communities of the two locations those ones of the Bükk Mountains are richer in species, due to the older age of their forests and their more humid, cooler climate. Perhaps forests of the Bükk Mountains are more sensitive to drought (see Fig. 2), than the submediterranean type forests of the Mecsek Mountains.

Functional spectra of macrofungal communities characterized well the monitored sampling plots and their environmental conditions. Since in years of extreme weather conditions the appearance of fruit bodies does not seem to represent the real species composition of the forests, it seemed reasonable to continue monitoring in the course of at least 3 years. Most endangered species are necrotrophic parasites (pn), which indicate impacts of human management with drastic decreases in fruit body numbers, or by complete disappearance. The other endangered group includes the wood-inhabiting saprotrophs (sh), from which many species disappear as a consequence of anthropogenic effects.

In both investigated locations the most structured lignicolous fungal communities can be found in the core areas of forest reserves: these are characterized by the highest number of species, with some dominant, several moderately rare and even more rare species. The least structured are the lignicolous assemblages of the plantations - here even the presence of any community organization can not be confirmed. In respect to rare species, the core areas are the richest in both locations, followed by the managed forests and finally by the plantations. In supporting the survival of the lignicolous fungi and the maintenance of the community structure the quantity and the composition of dead wood material in the forest reserves is very important. The diversity of dead wood material, serving as nutrient for different fungi, and the different stages of the decomposition process increase biodiversity significantly. 
Independently of the spatial position, the core areas have a lignicolous fungal community of typical functional composition and structure, which developed in a similar way in both locations (see Figs 1-6 and 11). Consequently, it can be presumed that the geographical position does not have a significant impact upon the functional composition and the structure of the fungal communities of forest reserves. In the case of the managed forests and the plantations, however, presumably as a consequence of the limited availability of dead wood, the geographical location and the environmental factors are more important determining factors of the forest structure and functional composition, than the degree of naturalness of forests. Dead wood seems to influence the functional composition and the structure of fungal communities in a similar way as rivers influence the species composition and the structure of azonal plant communities.

Soil-inhabiting fungal communities of the managed forests and the plantations show a relatively varied, diverse structure in both locations. It is surprising, that - in contrast with the lignicolous fungal communities - the soil-inhabiting fungal communities of the core areas have less species and a more simple structure than the managed forests and the plantations. Nevertheless, the species compositions of the soil-inhabiting fungal communities of the two locations are different. Presumably the appearance of fungal species connected to the special tree species of the managed forests and the plantations makes these communities more diverse. This higher diversity, however, is not accompanied by an increased number of species of high nature conservation value. On the basis of the results presented it can be concluded, that the composition of the soil-inhabiting fungal communities is primarily influenced by the composition of the vegetation and the type of soil, whereas the state of naturalness of the forest and the type of its management are less important determining factors.

In the separate years only a part of the fungal species present in the habitats produces fruit bodies. Consequently, in order to make the results of a mycological monitoring representative of the habitats, collection of data during several years is necessary. If also the results of our previous surveys are taken into consideration, the continuation of monitoring for at least 3 years seems to be required. Anyhow, for the comparison of functional groups, diversities and species compositions of fungal communities, monitoring of 3 years seems to be enough.

The present mycological monitoring confirmed that forest reserves are very important as refugia for fungi, and offer a possibility for them to spread later into the area of presently managed forests, too. During our monitoring some species were found, which are good indicators of certain characteristics (e.g. degree of naturalness, age, availability of dead wood and completeness of the decay cycle) of forests.

Our results support that the protocol elaborated in the frame of HBMS is suitable for a mycologically based comparison of different forests, furthermore for the evaluation of the state of forests. Additionally, long-term monitoring can help in the recognition and description of forest development processes, changes and trends.

Importances of long-term monitoring of fungal communities are as follows:

1) basic data are collected about changes in the species and functional composition of the fungal communities,

2) standardized sampling offers an opportunity for comprehensive comparisons as well as observations of dynamics and trends of scientific demand, 
3) on the basis of long-term monitoring of fungal communities in different geographical regions and in forests under different management practices, additional indicator species can be identified,

4) within the same sampling locations significance can be demonstrated between the results of fungal monitoring and some other components monitored (e.g. characteristics of the vascular vegetation or the abiotic environment); as a consequence, indicative characteristics of fungi can be used in the frame of comlex studies.

5) mycological monitoring confirms that forest reserves are very important as refugia for fungi, and offer a possibility for them to spread later into the area of presently managed forests, too,

6) it makes possible a better estimation of the threatened status of species.

Acknowledgements: Our monitoring activity was supported by the Hungarian Ministry of Environment and Water in the framework of the Hungarian Biodiversity Monitoring System and the Faculty of Veterinary Sciences of the Szent István University (NKB-2002-KUT-6). We are grateful to Dr Béla Tóthmérész for his help in data processing and to Dr Gábor Jancsó and Dr Gábor Turcsányi for the linguistic correction.

\section{REFERENCES}

Ambrosi P., Bertagnolli A., Confalonieri M., La Porta N., Marchetti F., Maresi G., Minerbi S., Salvadori C., Valentinotti R. 2002. Eight years of integrated monitoring in Alpine forest ecosystems of Trentino and South Tyrol, Italy. (In:) R. Mos ello, B. Petriccion e, A. Marchetto (eds). Long-term ecological research in Italian forest ecosystems. J. Limnol. 61 (1): 137-147.

Arnolds E. 1988. The changing macromycete flora in the Netherlands. Trans. Br. Mycol. Soc. 90 (3): 391-406.

Arnolds E., Kuyper Th. W., Noordeloos M. E. 1995. Overzicht van de paddestoelen in Nederland. Nederlandse Mycologische Verenigung, Wijster.

Arnolds E., Veerkamp M. 1999. Gids voor de paddestoelen in het meetnet. Nederlandse Mycologische Verenigung, Baarn.

Dudka I. O., Merezhko T. O., Hayova V. P. 1994. Mycological monitoring for estimation and prognosis of the situation in forest ecosystem. Ukrainian Botanical Journal 51 (6): 53-59.

Fellne r R. 1989. Mycorrhizae-forming fungi as bioindicators of air pollution. Agriculture, Ecosystems and Environment 28: 115-120.

Felln e r R., S o u ku p F. 1991. Mycological monitoring in the air-polluted regions of the Czech Repubic. Commun. Institute Forestalis Chechoslovaca 17: 125-137.

Fo d o r L. 2003. Nagygombák rendszertani, környezettani és társulástani vizsgálata a Szigetközben. PhD értekezés. (Investigation of macrofungi in Szigetköz, their taxonomy, habitat and plant associations. PhD dissertation) Szent István Egyetem, Kertészettudományi Kar, Budapest.

Fodor L., Pál-Fám F. 2000. Comparative study on niche-substrate distribution of a lowland and a mountain hornbeam-oakwood's mushroom communities. Lippai János - Vas Károly Tudományos Ülésszak, SZIE, Budapest.

Ha a s H., Ko s t G. 1985. Basidiomycetenflora des Bannwaldes „Waldmoor-Torfstich”. Waldschutzgebiete in Rahmen der Mitteilungen der Forstlichen Versuchs- und Forschungsanstalt. Band 3: 105-123.

Høiland K., Bendiksen E. 1996. Biodiversity of wood-inhabiting fungi in a boreal coniferous forest in Sør-Trøndelag County, central Norway. Nordic Journal of Botany 16: 643-659.

Kárász I., S uba J. 1982. A bükki „Öserdő” cönológiai és florisztikai viszonyai. Fol. Hist.-nat. Mus. Matr. 8: 85-91.

Kost G., Ha as H. 1989. Die Pilzflora von Bannwäldern in Baden-Würtenberg. Waldschutzgebiete im Rahmen der Mitteilungen der Forstlichen Versuchs- und Forschunganstalt. Band 4: 9-182.

Krieglsteiner G. J. 1982. Die Makromyzeten des Bannwaldes „Steinhäusle”. Waldschutzgebiete in Rahmen der Mitteilungen der Forstlichen Versuchs- und Forschungsanstalt. Band 2: 77-88.

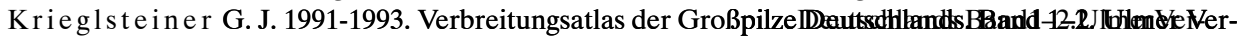
lag, Stuttgart. 
Ław ry nowicz M. 2001. Macromycetes of the oak forests in the Jurassic Landscape Park (Czestochowa Upland) - monitoring studies. Acta Mycologica 36 (1): 81-110.

Lawrynowicz M., Kałucka I., Sumorok B. 2001. Macromycetes of oak forests in the Lagiewnicki Forest (Central Poland) - monitoring studies. Acta Mycologica 36 (2): 303-326.

Lisiewska M., Polczynska M. 1998. Changes in macromycetes of oak-hornbeam forest in the Debina reserve (Northern Wielkopolska). Acta Mycologica 33 (2): 191-230.

Magurran A. E. 1988. Ecological diversity and its measurement. Croom Helm, New South Wales.

Matheis W. 1985. Die Discomyceten des Bannwaldes „Waldmoor-Torfstich”. Waldschutzgebiete in Rahmen der Mitteilungen der Forstlichen Versuchs- und Forschungsanstalt. Band 3: 125-136.

Moser M. 1983. Die Röhrlinge und Blätterpilze (Polyporales, Boletales, Agaricales, Russulales). Kleine Kryptogamenflora. II b/2. Basidiomyceten 2. VEB G. Fischer Verl. Jena.

Pál-Fám F. 1999. A nagygombák monitorozására kidolgozott próbaterv eredményei a Mecsek hegység két élőhelyén. Kézirat. KvVM, Természetvédelmi Hivatal, Budapest. (Results of the test plan to monitor macrofungi in two habitats of the Mecsek Mts. Report for the Authority for Nature Conservation.)

Pál-Fám F. 2001a. A Mecsek hegység nagygombái (és néhány mikrogomba), fungisztikai, ökológiai és cönológiai vizsgálatok. PhD értekezés. (Macrofungi of the Mecsek Mts. (and a few microfungi). Fungistical, ecological and coenological investigations. PhD dissertation.) Szent István Egyetem, Kertészettudományi Kar, Budapest.

Pál-Fám F. 2001b. Nagygomba cönológiai módszerek. Irodalmi összefoglaló. (Review of methods used in macrofungal coenology.) Botanikai Közlemények 88 (1-2): 145-172.

Podani J. 2001. SYN-TAX 2000. Computer programs for data analysis in ecology and systematics. Users' manual. Scientia, Budapest.

Renvall P. 1995. Community structure and dinamics of wood-rotting basidiomycetes on decomposing conifer trunks in northern Finland. Karstenia 35: 1-51.

Renvall P., Renvall T., Niemelä T. 1991. Basidiomycetes at the timberline in Lapland. 1-2. Karstenia 31 (1): 1-28.

Rimóczi I., Siller I., Vasas G., Albert L., Vetter J., Bratek Z. 1999. Magyarország nagygombáinak javasolt Vörös Listája. (Provisional Red List of macrofungi in Hungary.) Clusiana Mikológiai Közlemények 38 (1-3): 107-132.

Rimóc zi I., Pál-Fá m F. 1999. Javaslat a Nemzeti Biodiverzitás-monitorozó Rendszer kidolgozásához (átdolgozás). Kézirat. KvVM, Természetvédelmi Hivatal, Budapest. [Proposal for the elaboration of the National Biodiversity Monitoring System (second revision). Submitted to the Authority for Nature Conservation.]

Rimóczi I., Pál-Fám F., Sille r I., Jakucs E., Vasas G. 2000. Javaslat a nagygombák monitorozásának mintavételi módszereire a Nemzeti Biodiverzitás-monitorozó Rendszerben. (3. változat) Kézirat, KvVM Természetvédelmi Hivatal. [Proposal for the elaboration of the „Macrofungi” component of the National Biodiversity Monitoring System (third revision). Submitted to the Authority for Nature Conservation.]

Sille r I. 1986. Xilofág nagygombák cönológiai vizsgálata rezervátum és gazdasági bükkös állományokban. (Phytocoenological test of macrofungi in reservation and beech-wood cultivation.) Clusiana Mikológiai Közlemények 1986 (2-3): 95-115.

Sille r I. 1999. Ritka nagygombafajok a Kékes Észak erdőrezervátumban 1. (Rare macrofungi in the Kékes North forest reserve in the Mátra Mts., Hungary I.) Clusiana Mikológiai Közlemények 38 (1-3): 11-24.

Sille r I. 2004. Hazai montán bükkös erdőrezervátumok (Mátra: Kékes Észak, Bükk: Őserdő) nagygombái. PhD értekezés. [Macrofungi of montane beech forest reserves (Mátra Mountains: Kékes Észak, Bükk Mountains: Őserdő). PhD dissertation.] Szent István Egyetem, Kertészettudományi Kar Budapest.

Siller I., Turcsányi G., Maglóczky Zs., Czájlik P. 2002. Lignicolous macrofungi of the Kékes North Forest Reserve in the Mátra Mountains, Hungary. Acta Microbiologica et Immunologica 49 (2-3): 193-205.

Sille r I., Maglóczky Zs. 2002. Mikológiai vizsgálatok módszerei. (In:) F. Horváth, A. Borhidi (szerk.): Az erdőrezervátum-kutatás célja, koncepciója és módszerei. A KvVM Természetvédelmi Hivatalának Tanulmánykötetei 8. (Methods of mycological investigations. (In:) F. Horváth, A. Borhidi (eds). Aims, conceptions and methods of forest reserve investigations. TermészetBÚVÁR Alapítvány Kiadó, Budapest. 182-202. 
Sille r I., Pál-Fá m F., Fo d o r L. 2004. Erdők állapotváltozásának nyomon követése nagygombák segítségével. (Macrofungi as indicators of forest regeneration and forest developmental processes.) Természetvédelmi Közlemények 11: 185-194.

Skirgiełło A. 1998. Macromycetes of oak-hornbeam forests in the Bialowieza National Park - monitoring studies. Acta Mycologica 33 (2): 171-189.

Soder m a n G. (ed.) 1998. Master plan for monitoring biodiversity in Estonia. Environmental Information Centre, Tallin. PHARE

St ok land J. N. 2001. The coarse woody debris profile: an archive of recent forest history and an important biodiversity indicator. Ecological Bulletins 49: 71-84.

Tóthmérész B. 1993. NuCoSA 1.0: Number Cruncher for Community Studies and other Ecological Applications. Abstracta Botanica 7: 283-287.

Tóth mérész B. 1997. Diverzitási rendezések. (Diversity orderings.) Scientia, Budapest.

Tre czke r K., Sz a bó I. 2002. Farontó gombák a Ropolyi erdőrezervátumban. (Wood decay fungi from the forest reserve of Ropoly.) Clusiana Mikológiai Közlemények 41 (2-3): 67-94.

Veerkamp M., Kuyper T. W. 1993. Mycological investigations in forest reserves in the Netherlands. (In:) M. E. A.Broek meyer, W. Vos, H. Koop (eds). European forest reserves. Proceedings of the European forest reserves workshop, 6-8 May 1992, Wageningen: 127-143.

Whit ta ker R. H. 1970. Communities and ecosystems. 1st ed. Macmillan, New York.

Wint e r h off W. 1989. Die Bedeutung der baden-würtenbergischen Bannwälder für den Pilzartenschutz. Waldschutzgebiete in Rahmen der Mitteilungen der Forstlichen Versuchs- und Forschungsanstalt. Band 4: 183-190.

Wojew od a W., Heinrich Z., Kom orowsk a H. 1999. Macromycetes of oak-lime-hornbeam woods in the Niepołomice Forest near Kraków (S Poland) - monitoring studies. Acta Mycologica 34 (2): 201-266. 